\title{
Correction: Retinal vasculature in glaucoma: a review
}

Chan KKW, Tang F, Tham CCY, et al. Retinal vasculature in glaucoma: a review. BMJ Open Ophth 2017;1:e000032. doi: 10.1136/bmjophth-2016-000032.

The below funding statement should be included in this article:

The research funding is supported by Research Grants Council (RGC), Hong Kong. RGC Ref No. 14107516.

Open access This is an open access article distributed in accordance with the Creative Commons Attribution Non Commercial (CC BY-NC 4.0) license, which permits others to distribute, remix, adapt, build upon this work non-commercially, and license their derivative works on different terms, provided the original work is properly cited, appropriate credit is given, any changes made indicated, and the use is non-commercial. See:@http://creativecommons.org/licenses/by-nc/4.0/.

(C) Article author(s) (or their employer(s) unless otherwise stated in the text of the article) 2018. All rights reserved. No commercial use is permitted unless otherwise expressly granted.

BMJ Open Ophth 2018;3:e000032corr1. doi:10.1136/bmjophth-2016-000032corr1

(A) Check for updates 